\begin{tabular}{c} 
Brazilian Journal \\
of Chemical \\
Engineering \\
\hline
\end{tabular}

ISSN 0104-6632

Printed in Brazil

www.abeq.org.br/bjche

Vol. 30, No. 03, pp. 521 - 529, July - September, 2013

\title{
LAS DEGRADATION IN A FLUIDIZED BED REACTOR AND PHYLOGENETIC CHARACTERIZATION OF THE BIOFILM
}

\author{
L. L. Oliveira ${ }^{1 *}$, R. B. Costa ${ }^{1}$, I. K. Sakamoto ${ }^{1}$, I. C. S. Duarte ${ }^{2}$, \\ E. L. Silva ${ }^{3}$ and M. B. A. Varesche ${ }^{1^{*}}$ \\ ${ }^{1}$ Department of Hydraulics and Sanitation, School of Engineering of São Carlos, University of São Paulo, \\ Phone: + (55) (16) 3373-8356, Fax: + (55) (16) 3373-9550, \\ Av. Trabalhador Sãocarlense 400, CEP: 13566-590, São Carlos - SP, Brazil. \\ E-mail: lorenaloliveira@yahoo.com.br; varesche@sc.usp.br \\ ${ }^{2}$ Federal University of São Carlos, Rod. João Leme dos Santos, Km 110, SP 264, \\ CEP: 18052-780, Sorocaba - SP, Brazil. \\ ${ }^{3}$ Department of Chemical Engineering, Federal University of São Carlos, Rod. Washington Luiz, \\ Km 235, SP 310, CEP: 13565-905, São Carlos - SP, Brazil.
}

(Submitted: June 26, 2012 ; Revised: August 31, 2012 ; Accepted: October 26, 2012)

\begin{abstract}
A fluidized bed reactor was used to study the degradation of the surfactant linear alkylbenzene sulfonate (LAS). The reactor was inoculated with anaerobic sludge and was fed with a synthetic substrate supplemented with LAS in increasing concentrations ( 8.2 to $45.8 \mathrm{mg} \mathrm{l}^{-1}$ ). The removal efficiency of $93 \%$ was obtained after 270 days of operation. Subsequently, 16S rRNA gene sequencing and phylogenetic analysis of the sample at the last stage of the reactor operation recovered 105 clones belonging to the domain Bacteria. These clones represented a variety of phyla with significant homology to Bacteroidetes $(40 \%)$, Proteobacteria $(42 \%)$, Verrucomicrobia (4\%), Acidobacteria (3\%), Firmicutes (2\%), and Gemmatimonadetes $(1 \%)$. A small fraction of the clones $(8 \%)$ was not related to any phylum. Such phyla variety indicated the role of microbial consortia in degrading the surfactant LAS.

Keywords: Immobilized biomass; Sand; 16S rRNA, Aeromonas; Novosphingobium.
\end{abstract}

\section{INTRODUCTION}

Linear alkylbenzene sulfonate (LAS) is an anionic surfactant introduced in 1964 as the readily biodegradable replacement for highly branched AlkylBenzene Sulfonates (ABS). Since then, its consumption has increased considerably. The estimated world consumption in 2000 was of 2.5 million tons (Sanz et al., 2003).

LAS is one of the xenobiotic compounds frequently found in sewage and industrial wastewater. Its degradation has been widely studied in aerobic systems, and removal efficiencies of more than 97\% achieved (Brunner et al., 1988). However, for anaerobic systems, information is scarce and has been reported only recently, mainly due to recalcitrance of LAS in those systems. Removal efficiency of about $35 \%$ was achieved in horizontal anaerobic fixed bed (Duarte et al., 2008), and 85\% in Upflow Anaerobic Sludge Blanket (UASB) reactors (Sanz et al., 2003).

Regarding the microbial identification of organisms involved in LAS degradation, Lara-Martín et al. (2007) identified bacteria that could degrade LAS in marine sediments. They created a clone library showing high phylogenetic variety, which included members of the following classes: Alphaproteobacteria, Gamaproteobacteria (Pseudomonas).

*To whom correspondence should be addressed 
Firmicutes, Verrucomicrobia, Actinobacteria, Acidobacteria, Chloroflexi and Bacteroidetes were also detected. One of the identified clones showed 97\% sequence similarity to Desulfosarcina. Furthermore, Pseudomonas was present.

In recent research, Oliveira et al. (2010a, 2010b) studied the anaerobic degradation of LAS in a bench scale fluidized bed reactor filled with different support materials. The authors concluded that the anaerobic fluidized bed reactor containing immobilized biomass can be considered to be a feasible reactor configuration for treating LAS. The reactor's performance filled with sand reached an LAS removal efficiency of over $98 \pm 2 \%$ over the operating period, with LAS concentrations in the influent of $18.8 \pm 4.2 \mathrm{mg} \mathrm{l}^{-1}$. Regarding the molecular studies, the reactor presented wide microbial diversity, with microorganisms mainly belonging to the phyla Bacteroidetes, Firmicutes, Actinobacteria and Proteobacteria.

Thus, this work was focused on LAS degradation under anaerobic conditions in a fluidized bed reactor. Recent studies in this area have focused on the use of UASB and fixed bed reactors (Almendariz et al., 2001; Sanz et al., 2003; Duarte et al. 2008, Oliveira et al. 2009). The microbial communities from biomass present in the reactor were described by $16 \mathrm{~S}$ rRNA gene analysis. The microbial consortium present in the biofilm was probably involved in LAS degradation.

\section{MATERIAL AND METHODS}

\section{Reactor Operation}

Assays were performed in a fluidized bed reactor (FBR). The reactor was made of acrylic with a diameter of $4 \mathrm{~cm}$ and a height of $100 \mathrm{~cm}$. It was kept in a controlled temperature chamber $\left(30 \pm 1^{\circ} \mathrm{C}\right)$ and operated with a hydraulic retention time (HRT) of $18 \mathrm{~h}$. The inoculum used in the experiment came from an UASB reactor used to treat swine wastewater at the UNESP University (JaboticabalSP, Brazil). The seed sludge contained $36 \mathrm{~g} \mathrm{~L}^{-1}$ of volatile solids (VS). The reactor was kept in a closed circuit for biomass immobilization and adaptation to synthetic substrate. In this stage, $3 \mathrm{~L}$ of feed medium was prepared. This feed consisted of synthetic substrate, prepared as reported by Oliveira et al. (2010a) (approximately $560 \mathrm{mg} \mathrm{L}^{-1}$ of COD), and anaerobic sludge $(10 \% \mathrm{v} / \mathrm{v})$. The six experimental stages were defined by modifications to the composition of the synthetic substrate: Phase I, synthetic substrate without LAS; Phase II, synthetic substrate with $8.2 \mathrm{mg} \mathrm{L}^{-1}$ of LAS; Phase III, synthetic substrate with $24.4 \mathrm{mg} \mathrm{L}^{-1}$ of LAS; Phase IV, synthetic substrate with $30.8 \mathrm{mg} \mathrm{L}^{-1}$ of LAS; Phase $\mathrm{V}$, synthetic substrate with $38.4 \mathrm{mg} \mathrm{L}^{-1}$ of LAS and Phase VI, synthetic substrate with $45.8 \mathrm{mg} \mathrm{L}^{-1}$ of LAS.

\section{Physicochemical Analysis}

To assess the behavior of the FBR, the following parameters were measured: chemical oxygen demand (COD) and $\mathrm{pH}$ (APHA, 2005). Bicarbonate alkalinity (BA) in the form of $\mathrm{CaCO}_{3}$ was measured as described in Dillalo and Albertson (1961) with the modifications of Ripley et al. (1986). The LAS concentration was periodically measured in the liquid phase (influent and effluent) using highperformance liquid chromatography (HPLC) as previously described (Duarte et al., 2006). The final mass balance of LAS in the system was calculated to quantify LAS degradation. The amounts of LAS supplied, measured at the outlet and adsorbed by the support plus biomass in the reactor at the end of the experiment were used in the calculations.

\section{Molecular Biology}

The extraction of total DNA was performed using the phenol:chloroform-based protocol described by Griffiths et al. (2000). To construct a 16S rRNA gene library, amplification was performed using the bacterial primers $27 \mathrm{f}$ and $1100 \mathrm{f}$ (Lane, 1991). A 16S rRNA gene library was constructed from the sludge sample taken in the final stage of reactor operation. The purified PCR product was ligated into the pGEM-T Easy Vector (Promega, Madison, WI, USA) according to the manufacturer's instructions, and then transformed inside Escherichia coli JM109 cells. The 16S rRNA gene inserts were amplified from the plasmid DNA of selected clones using universal M13 forward and reverse primers (Invitrogen).

Phylogenetic assignment of the microorganisms in the reactor samples was achieved by comparing the 500-bp contiguous 16S rRNA gene sequences obtained with 16S rRNA sequence data from reference and type strains and environmental clones deposited in the GenBank (http://www.ncbi.nlm.nih.gov) and RDP (Ribosomal Database Project, WI, USA, $\mathrm{http} / / /$ www.cme.msu.edu/RDP/html/index.html) public databases. Sequence matching was carried out using the BLAST and RDP routines.

The DEREPLICATE program was used to define the operational taxonomic units (OTUs). The alignment 
was done using ALIGNER with the default parameter settings. An evolutionary distance matrix was then calculated using the program COMPLETE LINKAGE CLUSTERING (http://pyro.cme.msu.edu/). The numbers and sequences of each OTU were determined based on an evolutionary distance of 0.05 .

The sequences from the different OTUs were aligned with RDP database sequences in MEGA 5.05. The phylogenetic relationships obtained were analyzed by the Neighbor-Joining method using the MEGA 5.05 software package. Bootstrap analysis was based on 100 re-samplings.

The nucleotide sequences determined in this study and included in the phylogenetic trees have been deposited in the Genbank under the accession numbers JX561117-JX561132.

\section{RESULTS AND DISCUSSION}

Table 1 presents the results in each of the six phases of reactor's operation, such as the initial and final concentrations of organic matter, $\mathrm{pH}$, bicarbonate alkalinity, total volatile acids and effluent LAS concentration, and its percentage of removal.

The percentage of organic matter removal in the first stage was similar to that found in fixed-bed reactors for LAS treatment (Oliveira et al. 2009). The reactors used in the previous study were fed with the same synthetic substrate and the mean value of COD removal was $87 \pm 3 \%$ for the biomass adaptation stage (Stage I).

The filtered COD values obtained in the second stage $(86 \pm 7 \%)$ indicated that LAS did not affect the organic matter degradation as occurred in the study of Oliveira et al. (2009). The other parameters remained constant and stable over the previous steps without LAS in the influent (Table 1).

The high values of COD removal in all stages indicated that LAS did not affect the organic matter degradation. This is possibly justified because the reactor is high-rate. The reactor's configuration allowed operation with a wide range of organic matter concentration. Furthermore, the development of a mature biofilm in the adaptation stage with cosubstrate (sucrose and yeast extract) favored the growth of active biomass capable of degrading LAS. In association with these possibilities, the recirculation rate must be highlighted because it favored surfactant dilution, and consequently the microbial degradation.

During the reactor's operation, the $\mathrm{pH}$, Bicarbonate Alkalinity and Total Volatile Acid of the effluent remained constant with mean values of 8.0, $152\left(\mathrm{mgCaCO}_{3} \mathrm{~L}^{-1}\right)$ and $15\left(\mathrm{mgHAc} \mathrm{L}^{-1}\right)$, respectively.

Table 1: Values of physicochemical parameters in the fluidized bed reactor

\begin{tabular}{|c|c|c|c|c|c|c|}
\hline \multirow{2}{*}{ Stage } & \multirow{2}{*}{ Sample } & $\operatorname{COD}_{\mathrm{f}}{ }^{\mathrm{a}}$ & \multirow{2}{*}{ pH } & $\mathbf{B A}^{\mathbf{b}}$ & TVA $^{\mathbf{c}}$ & LAS \\
\hline & & $\left(\mathrm{mg} \mathrm{l}^{-1}\right)$ & & $\left(\mathrm{mgCaCO}_{3} \mathrm{I}^{-1}\right)$ & $\left(\right.$ mgHAc $\left.I^{-1}\right)$ & $\left(\mathrm{mg} \mathrm{l}^{-1}\right)$ \\
\hline $\begin{array}{c}\text { I } \\
28 \text { days }\end{array}$ & $\begin{array}{l}\text { Influent } \\
\text { Effluent } \\
\text { Removal (\%) }\end{array}$ & $\begin{array}{r}698 \pm 58 \\
93 \pm 23 \\
87 \pm 3\end{array}$ & $\begin{array}{l}7.7 \pm 0.2 \\
8.1 \pm 0.2\end{array}$ & $289 \pm 125$ & $17 \pm 2$ & $\begin{array}{l}- \\
- \\
-\end{array}$ \\
\hline $\begin{array}{c}\text { II } \\
28 \text { days }\end{array}$ & $\begin{array}{l}\text { Influent } \\
\text { Effluent } \\
\text { Removal (\%) }\end{array}$ & $\begin{array}{r}644 \pm 39 \\
90 \pm 41 \\
86 \pm 7\end{array}$ & $\begin{array}{l}7.6 \pm 0.2 \\
8.1 \pm 0.2\end{array}$ & $151 \pm 17$ & $18 \pm 6$ & $\begin{array}{r}8.2 \pm 1.3 \\
0.9 \pm 0.9 \\
88 \pm 11\end{array}$ \\
\hline $\begin{array}{c}\text { III } \\
49 \text { days }\end{array}$ & $\begin{array}{l}\text { Influent } \\
\text { Effluent } \\
\text { Removal (\%) }\end{array}$ & $\begin{array}{r}665 \pm 50 \\
58 \pm 21 \\
91 \pm 3\end{array}$ & $\begin{array}{l}7.7 \pm 0.1 \\
8.0 \pm 0.2\end{array}$ & $143 \pm 12$ & $15 \pm 3$ & $\begin{array}{r}24.4 \pm 3.7 \\
1.1 \pm 1.2 \\
96 \pm 5\end{array}$ \\
\hline $\begin{array}{c}\text { IV } \\
49 \text { days }\end{array}$ & $\begin{array}{l}\text { Influent } \\
\text { Effluent } \\
\text { Removal (\%) }\end{array}$ & $\begin{array}{r}608 \pm 45 \\
42 \pm 12 \\
93 \pm 2 \\
\end{array}$ & $\begin{array}{l}7.7 \pm 0.2 \\
8.0 \pm 0.2\end{array}$ & $152 \pm 43$ & $12 \pm 3$ & $\begin{array}{r}30.8 \pm 4.5 \\
2.1 \pm 2.0 \\
93 \pm 6\end{array}$ \\
\hline $\begin{array}{c}\mathrm{V} \\
70 \text { days }\end{array}$ & $\begin{array}{l}\text { Influent } \\
\text { Effluent } \\
\text { Removal (\%) }\end{array}$ & $\begin{array}{r}639 \pm 30 \\
43 \pm 13 \\
93 \pm 2 \\
\end{array}$ & $\begin{array}{l}7.6 \pm 0.3 \\
8.1 \pm 0.2\end{array}$ & $146 \pm 6$ & $15 \pm 5$ & $\begin{array}{r}38.4 \pm 5.7 \\
2.5 \pm 1.2 \\
93 \pm 3 \\
\end{array}$ \\
\hline $\begin{array}{c}\text { VI } \\
47 \text { days }\end{array}$ & $\begin{array}{l}\text { Influent } \\
\text { Effluent } \\
\text { Removal (\%) }\end{array}$ & $\begin{array}{r}632 \pm 42 \\
60 \pm 17 \\
91 \pm 2 \\
\end{array}$ & $\begin{array}{l}7.6 \pm 0.2 \\
7.9 \pm 0.2\end{array}$ & $153 \pm 47$ & $14 \pm 6$ & $\begin{array}{r}45.8 \pm 5.4 \\
3.2 \pm 1.2 \\
93 \pm 3 \\
\end{array}$ \\
\hline
\end{tabular}

${ }^{\mathrm{a}} \mathrm{COD}_{\mathrm{f}}$ : Chemical Oxygen Demand filtered

${ }^{\mathrm{b}} \mathrm{BA}$ : Bicarbonate Alkalinity

${ }^{\mathrm{c}}$ TVA: Total Volatile Acid 
At the end of the reactor's operation, samples of support material were removed to perform the extraction of the adsorbed LAS. The result of LAS extraction from the sand was under the detection limit of the calibration curve $\left(0.49 \mathrm{mg} \mathrm{L}^{-1}\right)$. This indicates no adsorption of surfactant on the support or in the biofilm. Thus, the reactor received about $7760 \mathrm{mg}$ of LAS, and $510 \mathrm{mg}$ were collected in the effluent. The remaining LAS (93\%) was removed from the system by the biological degradation process.

In previous research with FBRs filled with different support materials, including sand, Oliveira et al. (2010a) obtained results similar to this work. The feed and operating conditions of the reactors were similar, but with a fixed concentration of about $15 \mathrm{mg} \mathrm{L}^{-1}$.of LAS. The degradation percentages were $86,83,98.5$ and $98.2 \%$ for the reactor filled with activated charcoal, expanded clay, glass beads and sand, respectively.

The reactor proved to be a suitable alternative for the treatment of LAS, especially when compared with the experiments carried out in horizontal anaerobic immobilized biomass (HAIB) reactors (Duarte et al., 2008; Oliveira et al., 2009). In those studies, the HAIB reactor was operated with a hydraulic retention time (HRT) of $12 \mathrm{~h}$ and fed with an LAS concentration of $14 \mathrm{mg} \mathrm{l}^{-1}$ during 313 and 343 days, respectively; $35 \%$ and $28 \%$ of the input LAS were degraded. In the reactor used in the present study, the percentage of degradation was constantly higher. The difference in degradation must reflect the different configurations of the systems and the microorganisms that developed inside them, because all reactors were fed with the same synthetic substrate and inoculum. Therefore, it is likely that the hydrodynamic characteristics of the system, which is a mixing reactor, combined with other parameters such as $\mathrm{pH}$ and alkalinity, promoted the growth of different microorganisms.

Table 2 shows the comparison of this work with others, cited above.

\section{Identification of Microorganisms Possibly Responsible for LAS Degradation}

A 16S rRNA gene library was constructed to evaluate the bacterial community composition of the biomass at the end of the reactor operation period (270 days). A total of 110 clones were obtained from the biofilm in the sand reactor bed. The clone library obtained showed a high phylogenetic diversity, with members from six phyla: $41.8 \%$ of the clones were assigned to the phylum Proteobacteria, $40 \%$ to Bacteroidetes, $3.6 \%$ to Verrucomicrobia, $2.7 \%$ to Acidobacteria, $1.8 \%$ to Firmicutes, $0.9 \%$ to Gemmatimonadetes and $0.9 \%$ to Fusobacteria. A small proportion of clones $(8.2 \%)$ were not assigned to any phylum.

Figure 1 represents the clone percentages in the reactor sample related to different phylum. Although this comparison is represented as a percentage, it is not a quantitative representation of the microorganisms present in the reactor, but a qualitative one.

In a fluidized bed reactor operated on a smaller scale with the same support material and operating conditions for 70 days, Oliveira et al. (2010b) obtained the following classification as regards the Phyla: Bacteroidetes (25\%), Proteobacteria (25\%), Actinobacteria (12\%), Deinococcus-Thermus (12\%), Firmicutes (5\%), Acidobacteria (3\%), Anaerolineae $(2 \%)$, Gemmatimonadetes (2\%), Nitrospira (2\%). In the present research lower microbial diversity was observed, which can be related to a potential selection of microorganisms by the higher concentration of surfactant.

Table 2: Comparative study of the efficiency of LAS removal in anaerobic reactors.

\begin{tabular}{|c|c|c|c|c|c|c|c|}
\hline $\begin{array}{c}\text { Reactor } \\
\text { configuration }\end{array}$ & \begin{tabular}{|c|}
$\begin{array}{c}\text { Operation } \\
\text { period } \\
\text { (days) }\end{array}$ \\
\end{tabular} & Support material & Inoculum & $\begin{array}{l}\text { Input } \\
\text { (mg) }\end{array}$ & $\begin{array}{c}\text { Degradati } \\
\text { on }(\%)\end{array}$ & $\begin{array}{c}\text { Phylogenetic } \\
\text { characterization } \\
\text { (predominance) } \\
\end{array}$ & Reference \\
\hline HAIB $^{*}$ & 313 & $\begin{array}{l}\text { polyurethane } \\
\text { foam }\end{array}$ & $\begin{array}{l}\text { sludge from a } \\
\text { sanitary sewage } \\
\text { treatment }\end{array}$ & 5,782 & 35 & $\begin{array}{l}\text { Phylum Firmicutes } \\
\text { Class Clostridia } \\
\text { Order Clostridiales }\end{array}$ & $\begin{array}{l}\text { Duarte et al., } \\
2008\end{array}$ \\
\hline $\begin{array}{l}\text { Anaerobic stirred } \\
\text { sequencing-batch }\end{array}$ & 122 & $\begin{array}{l}\text { granular biomass } \\
\text { without support }\end{array}$ & $\begin{array}{l}\text { UASB reactor } \\
\text { treating swine } \\
\text { wastewater }\end{array}$ & 13,100 & 53 & Phylum Bacteroidetes & $\begin{array}{l}\text { Duarte et al., } \\
2010 \mathrm{~b}\end{array}$ \\
\hline Fluidized bed & 79 & $\begin{array}{l}\text { glass beads } \\
\text { sand }\end{array}$ & $\begin{array}{l}\text { UASB reactor } \\
\text { treating swine } \\
\text { wastewater }\end{array}$ & 385 & $\begin{array}{l}98.5 \\
98.2\end{array}$ & $\begin{array}{l}\text { Phylum Proteobacteria } \\
\text { Phyla Proteobacteria } \\
\text { and Bacteroidetes }\end{array}$ & $\begin{array}{l}\text { Oliveira et al., } \\
2010 \mathrm{~b}\end{array}$ \\
\hline Fluidized bed & 270 & sand & $\begin{array}{l}\text { UASB reactor } \\
\text { treating swine } \\
\text { wastewater }\end{array}$ & 7,760 & 93 & $\begin{array}{l}\text { Phyla Proteobacteria } \\
\text { and Bacteroidetes } \\
\text { Class Sphingobacteria }\end{array}$ & this study \\
\hline
\end{tabular}

"Horizontal-Flow Anaerobic Immobilized Biomass 


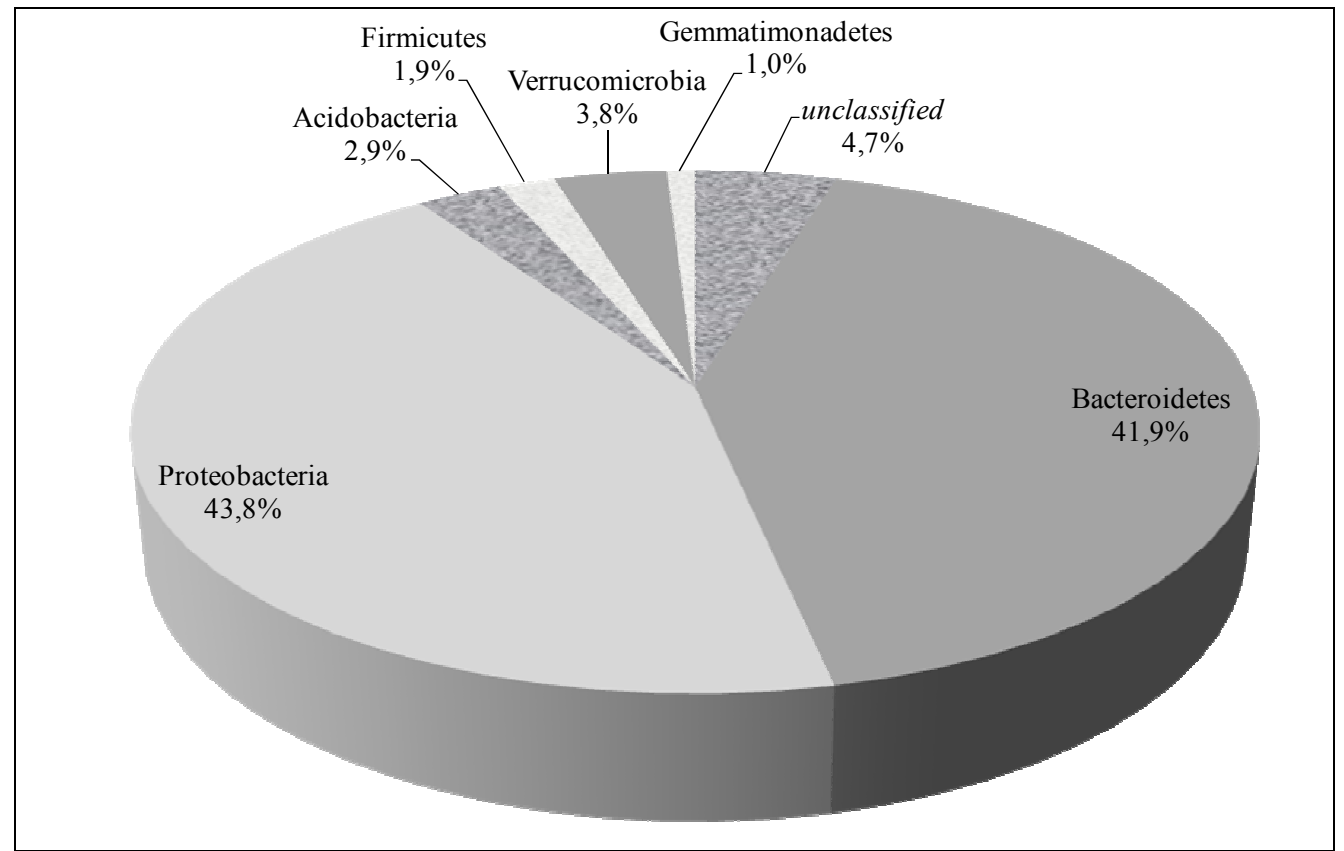

Figure 1: Phylogenetic representation of the microorganisms sampled during FBR operation

A total of 44 clones were related to the phylum Bacteroidetes, with 42 belonging to Class Sphingobacteria. The cells of species in this Class are gramnegative, non-spore-forming, straight rods that have no flagella but may exhibit sliding motility. Acid is produced from carbohydrates oxidatively but not fermentatively (Yabuuchi et al., 1983). Niastela sp. (related to 3 clones with $92 \%$ similarity) and Terrimonas sp. (related to 12 clones with $83 \%$ similarity), belonging to this Class, were also found in another reactor filled with sand (Oliveira et al., 2010b). The former is Gram-negative, aerobic, nonflagellated, gliding and filamentous. It was isolated from soil cultivated with Korean ginseng (Weon, H., et al., 2006). The latter is a nitrogen fixator, aerobic, gram-negative and filamentous. It was isolated from garden soil (Xie and Yokota, 2006). Sediminibacterium sp. and Ferruginibacter sp. were also similar to some OTUs. Sediminibacterium sp. is aerobic, Gramnegative rods, phylogenetically related to the genera Terrimonas and Niastella in the phylum Bacteroidetes ( $\mathrm{Qu}$ and Yuan, 2008). In this research, they were similar to microorganisms present in activated sludge. Ferruginibacter sp. is gram-negative, aerobic, nongliding, nonfilamentous single rods (Lim et al., 2009). The OTUs were similar to organisms present in water supply systems, in estrogen-degrading bioreactors, in soil and sea sediments receiving agricultural discharges.

Similarly to Oliveira et al. (2010b), the Phylum Proteobacteria represented a significant proportion of clones obtained (46), but in the present study, the
Class Betaproteobacteria (presenting bacteria highly versatile in their degradation abilities) was more effective with 27 clones. Clones classified as Alphaproteobacteria (14), Gammaproteobacteria (4) and Deltaproteobacteria (1) were also obtained, differently from Oliveira et al. (2010b).

Three clones were related to Aeromonas sp. (100\% sequence homology). It has been suggested that this genus degrades surfactants. Jimenez et al. (1991) studied a mixed microbial community consisting of three species of Pseudomonas and one Aeromonas sp. LAS was added at a concentration of $1 \mathrm{mg} \mathrm{ml}^{-1}$ as the only source of carbon, and all species studied were able to degrade over $25 \%$ of the input LAS and convert it to $\mathrm{CO}_{2}$. Duarte et al. (2010) also found clones related to Pseudomonas in anaerobic batch reactor treating detergent.

Another clone was identified as Novosphingobium, with $99 \%$ sequence similarity. This genus may also have contributed to LAS degradation in the present study, as it has been shown to use the aromatic ring of LAS as a carbon source (Sohn et al., 2004). Moreover, this genus was also found in the sequencing of a batch anaerobic reactor treating detergent (Duarte et al., 2010).

Some clones were related to the genus Rhodobacter (98\%) and Novispirillum (99\%) belonging to the Phylum Proteobacteria, Class Alphaproteobacteria. In general, they are aerobic, anaerobic or facultative, gram-negative microorganisms, with broad metabolic capabilities, found in sewage treatment plants (Bergey and Holt, 1994). 
Some clones were related to denitrifying bacteria (Alicycliphilus, 99\%) (Heylen et al., 2006) and a nitrogen-fixing bacterium isolated from rice paddy soil (Zoogloea, 91-99\%) (Xie and Yokota, 2006). These bacteria belong to the Class Betaproteobacteria. A clone was related to Azospira sp. with 99\% similarity. This organism uses aromatic compounds. It was isolated from contaminated soils and water and catabolized benzoate and other aromatic compounds anaerobically (Bergey and Holt, 1994). The presence of Azospira sp. in a fluidized bed reactor fed with LAS can be justified by the aromatic ring linked to the sulfonate group in the surfactant molecule.

Several members of the phylum Firmicutes (family Clostridiales) can use xenobiotic compounds as electron acceptors. Therefore, these should be considered as possibly being responsible for the anaerobic degradation of LAS. In fact, several species of the order Clostridia can desulfonate alkyland arylsulfonates (Duarte et al., 2010). Some clones sequenced in this study were related to Clostridium $\mathrm{sp}$. The reactor's nutritional composition favored the growth of these cells, since both carbohydrates and amino acids (yeast extract) were available.

To illustrate the microbial diversity, the phylogenetic tree related to Phylum Proteobacteria was constructed (Figure 2). Thus, the sequences (exceeding $600 \mathrm{bp}$ ) were grouped into operational taxonomic units (OTUs) with more than $95 \%$ similarity. Table 3 shows the clones present in Figure 2 classified in OTUs, as well their similarity to sequences with access number in NCBI and the reference.

Table 3: Sequences obtained from Genbank related to clones in the reactor, Phylum Proteobacteria

\begin{tabular}{|c|c|c|c|c|c|}
\hline OTU & $\begin{array}{l}\text { Number of } \\
\text { Clones }\end{array}$ & $\begin{array}{l}\text { Similarity } \\
(\%)\end{array}$ & Access NCBI & Description & Reference \\
\hline 01 & 2 & 98 & AY244771 & $\begin{array}{l}\text { Rhodobacter sp. 2002-65602 16S ribosomal RNA } \\
\text { gene, partial sequence }\end{array}$ & $\begin{array}{l}\text { Drancourt, et al., } \\
\text { unpublished }\end{array}$ \\
\hline 02 & 6 & 99 & AM697216 & $\begin{array}{l}\text { Uncultured bacterium partial 16S rRNA gene, isolate } \\
\text { BF0001C } 057\end{array}$ & $\begin{array}{l}\text { Rintala et al., } \\
2008\end{array}$ \\
\hline 03 & 2 & 99 & AB680932 & $\begin{array}{l}\text { Novispirillum itersonii subsp. itersonii gene for } 16 \mathrm{~S} \\
\text { rRNA, partial sequence, strain: NBRC } 15648\end{array}$ & $\begin{array}{l}\text { Nakagawa et al., } \\
\text { unpublished }\end{array}$ \\
\hline 04 & 1 & 99 & HM066524 & $\begin{array}{l}\text { Uncultured bacterium clone EDW07B003_75 } \\
\text { ribosomal RNA gene, partial sequence }\end{array}$ & $\begin{array}{l}\text { Gray and Engel, } \\
\text { unpublished }\end{array}$ \\
\hline 05 & 1 & 99 & FJ527720 & $\begin{array}{llll}\begin{array}{l}\text { Novosphingobium subterraneum strain } \\
\text { ribosomal RNA gene, partial sequence }\end{array} & & 16 \mathrm{~S} \\
\end{array}$ & $\begin{array}{l}\text { Liang and } \mathrm{Li}, \\
\text { unpublished }\end{array}$ \\
\hline 06 & 1 & 99 & JN038823 & $\begin{array}{l}\text { Uncultured beta proteobacterium clone P-R36 16S } \\
\text { ribosomal RNA gene, partial sequence }\end{array}$ & $\begin{array}{l}\text { Zhang et al., } \\
\text { unpublished }\end{array}$ \\
\hline 07 & 3 & 99 & AM084015 & $\begin{array}{l}\text { Alicycliphilus sp. R-24604 16S rRNA gene, strain } \\
\text { R-24604 }\end{array}$ & $\begin{array}{l}\text { Heylen et al., } \\
2006\end{array}$ \\
\hline 08 & 2 & 97 & JF834291 & $\begin{array}{l}\text { Bacterium enrichment culture clone phytdeg } 3316 \mathrm{~S} \\
\text { ribosomal RNA gene, partial sequence }\end{array}$ & $\begin{array}{l}\text { Dawson et al., } \\
\text { unpublished }\end{array}$ \\
\hline 09 & 1 & 99 & FJ393084 & $\begin{array}{l}\text { Uncultured Azospira sp. clone MFC-B162-C02 16S } \\
\text { ribosomal RNA gene, partial sequence }\end{array}$ & $\begin{array}{l}\text { Borole et al., } \\
2009\end{array}$ \\
\hline 10 & 4 & 100 & JF808857 & $\begin{array}{l}\text { Uncultured bacterium clone } \mathrm{R} 15-38 \text { 16S ribosomal } \\
\text { RNA gene, partial sequence }\end{array}$ & $\begin{array}{l}\text { Xia et al., } \\
\text { unpublished }\end{array}$ \\
\hline 11 & 1 & 98 & EF648041 & $\begin{array}{l}\text { Uncultured bacterium clone HB31 16S ribosomal } \\
\text { RNA gene, partial sequence }\end{array}$ & $\begin{array}{l}\text { Wang et al., } \\
\text { unpublished }\end{array}$ \\
\hline 12 & 1 & 94 & AB201044 & $\begin{array}{l}\text { Zoogloea oryzae gene for } 16 \mathrm{~S} \text { rRNA, partial sequence, } \\
\text { strain: A-4 }\end{array}$ & $\begin{array}{l}\text { Xie and Yokota, } \\
2006\end{array}$ \\
\hline 13 & 1 & 91 & AB201044 & $\begin{array}{l}\text { Zoogloea sp. gene for 16S rRNA, partial sequence, } \\
\text { strain: A-4 }\end{array}$ & $\begin{array}{l}\text { Xie and Yokota, } \\
2006\end{array}$ \\
\hline 14 & 4 & 99 & AB201044 & $\begin{array}{l}\text { Zoogloea oryzae gene for } 16 \mathrm{~S} \text { rRNA, partial sequence, } \\
\text { strain: A-4 }\end{array}$ & $\begin{array}{l}\text { Xie and Yokota, } \\
2006\end{array}$ \\
\hline 15 & 1 & 93 & JF834291 & $\begin{array}{l}\text { Bacterium enrichment culture clone phytdeg33 16S } \\
\text { ribosomal RNA gene, partial sequence }\end{array}$ & $\begin{array}{l}\text { Dawson et al., } \\
\text { unpublished }\end{array}$ \\
\hline 16 & 2 & 99 & AY548934 & $\begin{array}{l}\text { Uncultured bacterium clone 1-7 16S ribosomal RNA } \\
\text { gene, partial sequence }\end{array}$ & $\begin{array}{l}\text { Luo and } \mathrm{Hu}, \\
\text { unpublished }\end{array}$ \\
\hline 17 & 2 & 99 & FM207908 & $\begin{array}{l}\text { Uncultured Rhodocyclaceae bacterium partial } 16 \mathrm{~S} \\
\text { rRNA gene, clone } 408\end{array}$ & $\begin{array}{l}\text { Rotaru et al., } \\
2010\end{array}$ \\
\hline 18 & 1 & 99 & HM921148 & $\begin{array}{l}\text { Uncultured bacterium clone cpw3d216 16S ribosomal } \\
\text { RNA gene, partial sequence }\end{array}$ & $\begin{array}{l}\text { White } \text { et al., } \\
\text { unpublished }\end{array}$ \\
\hline 19 & 1 & 94 & DQ315383 & $\begin{array}{l}\text { Aeromonas sp. ZL1-r 16S ribosomal RNA gene, } \\
\text { partial sequence }\end{array}$ & $\begin{array}{l}\text { Zhang et al., } \\
\text { unpublished }\end{array}$ \\
\hline 20 & 2 & 100 & AY987730 & $\begin{array}{l}\text { Aeromonas schubertii strain AE- } 48 \text { 16S ribosomal } \\
\text { RNA gene, complete sequence }\end{array}$ & $\begin{array}{l}\text { Jangid et al., } \\
\text { unpublished }\end{array}$ \\
\hline
\end{tabular}




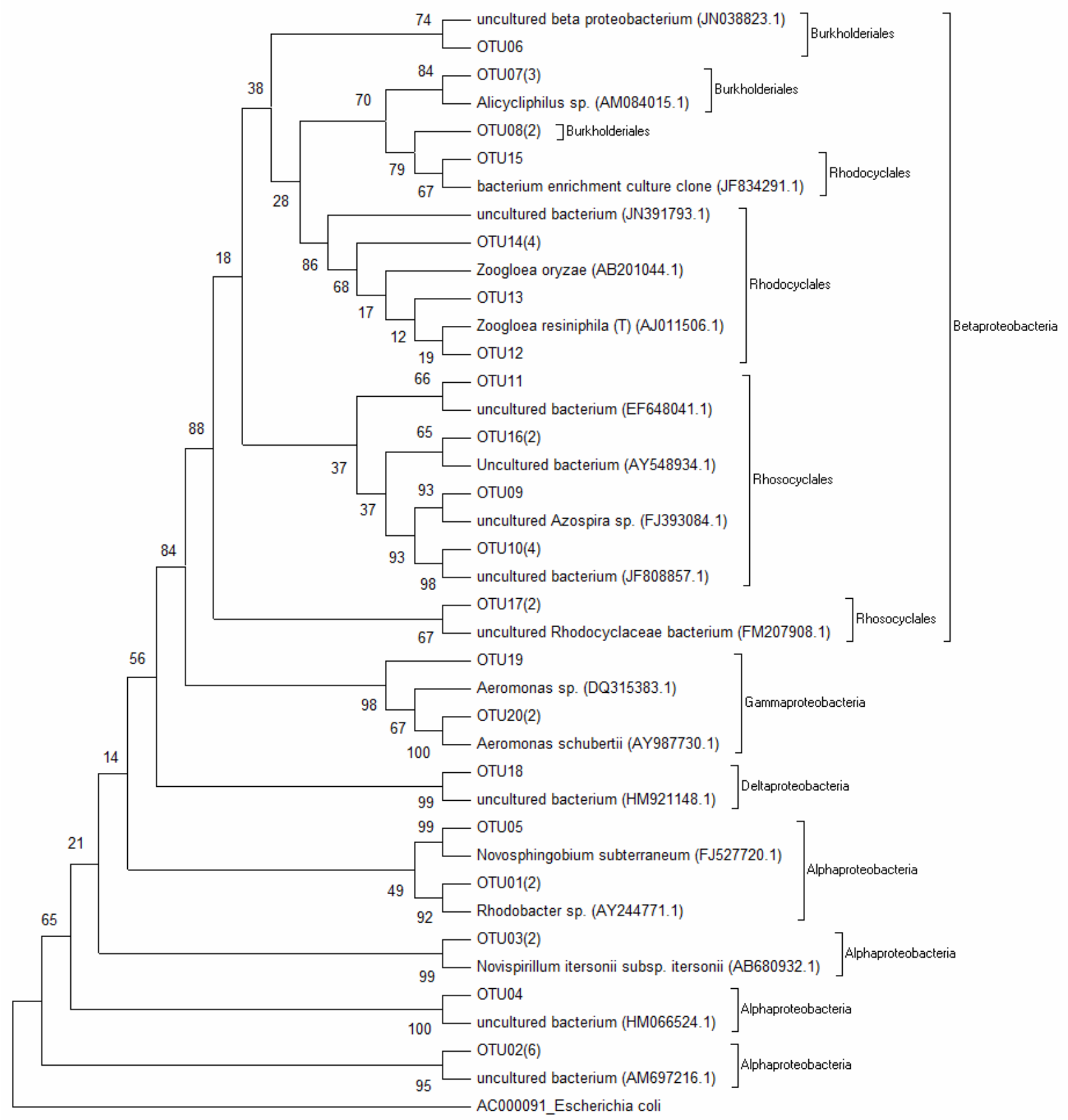

Figure 2: Phylogenetic analysis of partial 16S rRNA gene sequences of clones derived from the bioreactor sample and related microorganisms (Phylum Proteobacteria). The source of these clones and their Genbank accession numbers are listed after species names. Eschericha coli (AC000091) was used as an outgroup.

\section{CONCLUSIONS}

An anaerobic fluidized bed reactor with biofilm in sand was efficient for LAS removal, which was not affected by variations in the influent concentration. The COD removal remained high (above 90\%) and stable under all studied conditions, even with the increase of LAS concentration.

By means of phylogenetic analyses, it was verified that the degradation of LAS occurred in the presence of a syntrophic mixed microbial community. This identification may help to elucidate the 
possible bacteria present in the microbial consortium established in biofilms involved in LAS degradation. For example, Aeromonas spp., Novosphingobium spp. and Azospira spp. seemed to have a potential role in LAS degradation. Aeromonas spp. may use the molecule as a source of carbon or energy, Novosphingobium spp. and Azospira spp. may use the aromatic ring of the LAS molecule as a source of carbon and energy.

\section{ACKNOWLEDGEMENTS}

The authors gratefully acknowledge the grants received from FAPESP, Process No. 05/58968-4, Brazil.

\section{REFERENCES}

Almendariz, F. J., Meráz, M., Soberón, G., Monroy, O., Degradation of linear alkylbenzene sulphonates (LAS) in an acidogenic reactor bioaugmented with a Pseudomonas aeruginosa (M113) strain. Water Science Technology 44, 183-188 (2001).

APHA/AWWA/Water Environment Federation. Standard Methods for the Examination of Water and Wastewater. 20th Ed. Washington, DC, USA (2005).

Bergey, D. H., Holt, J. G., Bergey's Manual of Determinative Bacteriology. Ed. Williams \& Wilkins, $9^{a}$ Edition. (books.google.com.br) (1994).

Borole, A. P., Hamilton, C. Y., Vishnivetskaya, T. A., Leak, D., Andras, C., Morrell-Falvey, J., Keller, M. and Davison, B., Integrating engineering design improvements with exoelectrogen enrichment process to increase power output from microbial fuel cells. J. Power Sources, 191(2), 520-527 (2009).

Brunner, P. H., Capri, S., Marcomini, A., Giger, W., Occurrence and behaviour of linear alkylbenzenesulphonates, nonylphenol, nonylphenol monoand nonylphenol diethoxylates in sewage and sewage sludge treatment. Water Research, 22, 1465-1472 (1988).

Dillalo, R., Albertson, O. E., Volatile acids by direct tritation. Journal WPCF, 33, 356-365 (1961).

Duarte, I. C. S., Oliveira, L. L., Buzzini, A. P., Adorno, M. A. T., Varesche, M. B. A., Development of a method by HPLC to determine LAS and its application in anaerobic reactors. Journal Brazilian Chemical Society, 17, 1360-1367 (2006).

Duarte, I. C. S., Oliveira, L. L., Mayor, M. S., Okada, D. Y., Varesche, M. B. A., Degradation of detergent (linear alkylbenzene sulfonate) in an anaerobic stirred sequencing batch reactor containing granular biomass. International Biodeterioration and Biodegradation, 64, 120-143 (2010).

Duarte, I. C. S., Oliveira, L. L., Saavedra, N. K. D., Fantinatti-Garboggini, F., Oliveira, V. M., Varesche, M. B. A., Evaluation of the microbial diversity in a horizontal-flow anaerobic immobilized biomass reactor treating linear alkylbenzene sulfonate. Biodegradation, 19, 375-385 (2008).

Griffiths, R. I., Whiteley, A. S., O’Donnell, A. G., Rapid method for coextration of DNA from natural environments for analysis of ribossomal DNA and rRNA-based microbial community composition. Applied and Environmental Microbiology, 66, 5488-5491 (2000).

Heylen, K., Vanparys, B., Wittebolle, L., Verstraete, W., Boon, N., De Vos, P., Cultivation of denitrifying bacteria: Optimization of isolation conditions and diversity study. Applied and Environmental Microbiology, 72(4), 2637-2643 (2006).

Jimenez, L., Breen, A., Thomas, N., Federle, T. W., Sayler, G., Mineralization of linear alkylbenzene sulfonate by a four-member aerobic bacterial consortium. Applied and Environmental Microbiology, 57, 1566-1569 (1991).

Lane, D. J., 16S/23S rRNA Sequencing in Nucleic Acid Techniques. In Bacterial Systematics, Eds. Stackenbrandt, E. and Goodfellow, M. pp. 115148, New York: John Wiley and Sons, Inc (1991).

Lara-Martín, P. A., Gómez-Parra, A., Köchling, T., Sanz, J. L., Amils, R., González- Mazo, E., Anaerobic degradation of linear alkylbenzene sulfonates in coastal marine sediments. Environmental Science and Technology, 41, 3573-3579 (2007).

Lim, J. H., Baek, S. H., Lee, S. T., Ferruginibacter alkalilentus gen. nov., sp. nov. and Ferruginibacter lapsinanis sp. nov., novel members of the family 'Chitinophagaceae' in the phylum Bacteroidetes, isolated from freshwater sediment. Int. J. Syst. Evol. Microbiol., 59, 2394-2399 (2009).

Oliveira, L. L., Costa, R. B., Duarte, I. C. S., Silva, E. L., Varesche, M. B. A., Anaerobic degradation of linear alkylbenzene sulfonate in fluidized bed reactor. Braz. J. Chem. Eng., 27(4), 539-543 (2010a).

Oliveira, L. L., Costa, R. B., Okada, D. Y., Vich, D. V., Duarte, I. C. S., Silva, E. L., Varesche, M. B. A., Anaerobic degradation of linear alkylbenzene sulfonate (LAS) in fluidized bed reactor by microbial consortia in different support materials. Bioresource. Technology, 101, 5112-5122 (2010b). 
Oliveira, L. L., Duarte, I. C. S., Sakamoto, I. K., Varesche, M. B. A., Influence of support material on the immobilization of biomass for the degradation of linear alkylbenzene sulfonate in anaerobic reactors. Journal of Environmental Management, 90, 1261-1268 (2009).

Rintala, H., Pitkaranta, M., Toivola, M., Paulin, L. and Nevalainen, A., Diversity and seasonal dynamics of bacterial community in indoor environment. BMC Microbiol., 8, 56 (2008).

Ripley, L. E., Boyle, W. C., Converse, L. C., Improved alkalinetric monitoraing for anaerobic digestion of high-strength wastes. Journal WPCF, 58, 106-411 (1986).

Rotaru, A. E., Probian, C., Wilkes, H. and Harder, J., Highly enriched Betaproteobacteria growing anaerobically with p-xylene and nitrate FEMS Microbiol. Ecol., 71(3), 460-468 (2010).

Sanz, J. L., Culubret, E., de Ferrer, J., Moreno, A., Berna, J. L., Anaerobic biodegradation of linear alkylbenzene sulfonate (LAS) in upflow anaerobic sludge blanket (UASB) reactor. Biodegradation, 14, 57-64 (2003).

Sohn, J. H., Kwon, K. K., Kang, J. H., Jung, H. B., Kim, S. J., Novosphingobium pentaromativorans sp. nov., a high-molecular-mass polycyclic aromatic hydrocarbon-degrading bacterium isolated from estuarine sediment. Int. J. Syst. Evol. Microbiol., 54, 1483-1487 (2004).

Weon, H., Kim, B., Yoo, S., Lee, S., Kwon, S., Go, S., Stackebrandt, E., Niastella koreensis gen. nov., sp. nov. and Niastella yeongjuensis sp. nov., novel members of the phylum Bacteroidetes, isolated from soil cultivated with Korean ginseng. Int. J. Syst. Evol. Microbiol., 56, 1777-1782 (2006).

Xie, C., Yokota, A., Reclassification of [Flavobacterium] ferrugineum as Terrimonas ferruginea gen. nov., comb. nov., and description of Terrimonas lutea sp. nov., isolated from soil. Int. J. Syst. Evol. Microbiol., 56, 1117-1121 (2006).

Xie, C. H. and Yokota, A. Zoogloea oryzae sp. nov., a nitrogen-fixing bacterium isolated from rice paddy soil, and reclassification of the strain ATCC 19623 as Crabtreella saccharophila gen. nov., sp. nov. Int. J. Syst. Evol. Microbiol., 56 (PT 3), 619-624 (2006).

Yabuuchi, E., Kaneko, T., Yano, I., Moss, C. W., Miyoshi, N., Sphingobacterium gen. nov., Sphingobacterium spiritivorum comb. nov., Sphingobacterium multivorum comb. nov., Sphingobacterium mizutae sp. nov., and Flavobacterium indologenes sp. nov.: Glucose-nonfermenting gramnegative rods in CDC groups IIK-2 and IIb. Int. J. Syst. Bacteriol., 33, 580-598 (1983). 